\title{
COMMODIFICATION AND WOMEN'S HOUSEHOLD LABOR
}

\author{
Katharine Silbaugh ${ }^{\dagger}$
}

I. INTRODUCTION

II. THE COMMODIFICATION OBJECTION: SETTING OUT THE CASE AGAINST ECONOMICS

A. The Basic Problem with Commodification ..............................................84

B. A Taxonomy of Anticommodification Discourse ……...............................8

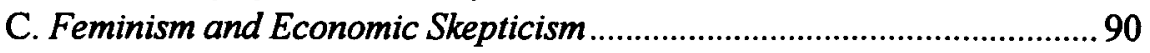

1. Offense at Economics....................................................................... 91

2. The Aptness of the Emotional Understanding...................................95

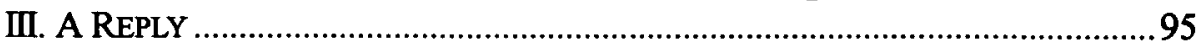

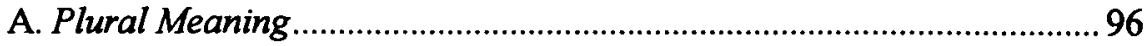

B. The Limited Influence of Talk in Legal Discourse: Plural Meaning

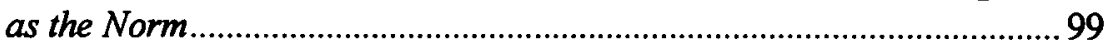

C. The Need for Economic Understandings of Home Labor in Particular

1. Comparison Between Commodification Concerns over Wage Labor Versus Home Labor ........................................................... 100

2. Women as Non-commodifiable: Questioning the Origins of an Idea

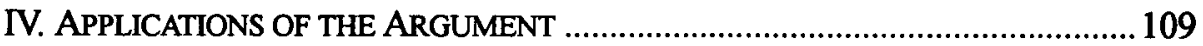

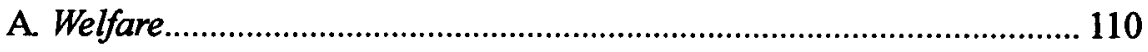

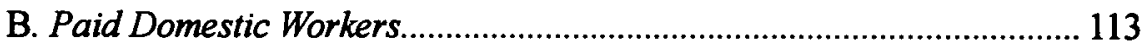

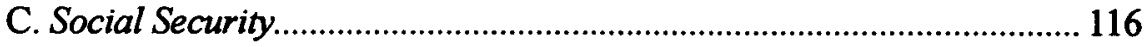

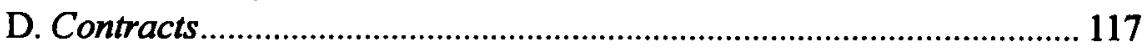

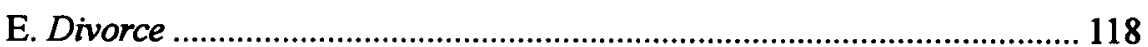

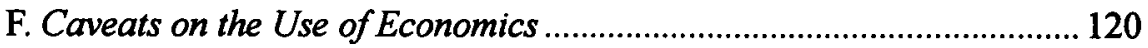

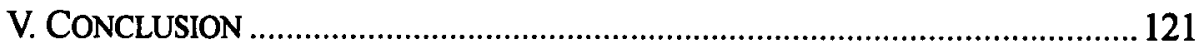

\section{INTRODUCTION}

A woman washes a kitchen floor. She puts the mop away and drives to the comer market. She consults a shopping list, and purchases groceries from it, carefully choosing the least expensive options. A four-year-old child is tugging at her leg while she does this, and she tries to entertain him, talking to him about the mopped floor, the grocery items. When she returns from the store, she

† Associate Professor, Boston University School of Law. I wish to thank Hugh Baxter, Daniela Caruso, Lawrence Lessig, Theodore Sims, Nancy Staudt and Jane Thrailkill for speedy and helpful comments on an earlier draft. I thank Jennifer Carter and Richard Palermo for research assistance.

Copyright ${ }^{\circ} 1997$ Katharine B. Silbaugh. Permission to reproduce at cost for classroom use is hereby granted, so long as copyright ownership and initial publication in the Yale Journal of Law and Feminism are identified. 
prepares lunch from what she has brought home with her. She and the child both eat lunch. After lunch, she and the child collect laundry and she runs a load. She takes the garbage out to the curb. Then she reads him a story. They play a game where she comes up with a word, and he tries to name its opposite. Sometimes there is no opposite, and that is particularly funny to both of them. She has done housework.

There is no way to tell from this description whether these activities were market or non-market, whether her work is a commodity or not. Would it help to categorize her work if you knew the location? Is this her home? Suppose that she is a paid domestic worker, and this housework is a commodity. She leaves her employer's home. She goes home and does exactly the same thing there, but this time she is preparing dinner. The second child is her own. Whether these activities are viewed as a commodity is contextual, not activity-based.

Should we think and talk about unpaid domestic labor-housework-using market, or economic, language? What follows is a defense of economic discourse on the subject of law and housework. It is written in response to the common criticism aimed at scholars who have examined domestic labor through an economic lens. It is a response to what is commonly called a "commodification critique," and particularly as that critique is formulated within feminist discourse.

In Turning Labor into Love: Housework and the Law, ${ }^{2}$ I examined the treatment of household labor in tax law, torts, family law, social security, welfare, contracts and labor law. I argued that characterizations of domestic labor by legal actors almost never include an emphasis on its economic productivity, instead focusing on housework as an expression of the affectionate emotions associated with the family setting where housework occurs. By setting up a dichotomy between the language of economic productivity and the language of emotions, I argued that legal actors have used the language of emotions to deny material security to those who perform domestic labor. From this I concluded that a more clearly articulated understanding of the economically productive aspects of home

1. See infra Part II.A. While I am not aware of anyone devoting an entire essay to this criticism, casual references are not uncommon. See, e.g., Grace Ganz Blumberg, Cohabitation Without Marriage: A Different Perspective, 28 UCLA L. REV. 1125 (1981). In arguing against computing the value of housework, Blumberg writes:

Her services are thus reduced to their domestic component; she is valued at a maid's salary. Surely, the last fifty years have produced no more degrading or useless formulation of the role and value of a homemaker. In addition, quantum meruit has a distressing tendency to commodify and hence to degrade what is probably the most important and certainly the most intimate human relationship.

Id. at 1165 (footnotes omitted). See also James Boyd White, Economics and Law: Two Cultures in Tension, 54 TENN. L. REV. 161 (1986). White argues against the use of market rhetoric:

The segmentation of the exchange model tends to misvalue the work we do for ourselves, which is most of the traditional work of women ... . This is especially true of people who raise their own children. Such work cannot be segmented into functions and then made the material of the market process, actual or hypothetical .... Similarly, housework has a different meaning when one is Id. at 190 . maintaining one's own home rather than acting as a servant for others.

2. Katharine Silbaugh. Turning Labor Into Love: Housework and the Law, 91 Nw. U. L. REv. 1 (1996). 
labor would, on balance, benefit those who perform the labor, who are still primarily women. ${ }^{3}$ I did not, however, address commodification problems with that conclusion. The most explicit writing on commodification in legal discourse has addressed the commodification of other aspects of women's experience: sexuality and reproduction. ${ }^{4}$ This critique has been raised in response to some recent work on domestic labor, including my own. ${ }^{5}$

I want to reject current categorical thinking about women's home activity. I argue that economic understandings are very useful, and that they do not and need not supply a complete understanding of human activities. I will make the case that economic understandings are representations of a given activity, as are sentimental or emotional understandings, and that they can and should co-exist. Margaret Jane Radin, the foremost legal scholar who has addressed commodification concerns, has also argued that multiple understandings can coexist. ${ }^{6} \mathrm{Her}$ goal, however, is to bring non-market understandings to market activities, in search of a less commodified society.

This Article questions that goal. My central argument is that the entirely emotional understanding of home labor is itself an impoverished one. If one conceded that the use of economic rhetoric could habituate people to thinking about a topic differently, as critics of economic language assert, that would not necessarily make the case against the use of such rhetoric in all contexts. I make the uncommon case here for the value of bringing market understandings to nonmarket activities where they can co-exist with non-economic conceptions. The broader implication of the thesis is that we should not assume that analyses that can remake relations are always doing a disservice, especially where those relations are already fraught with problematic analyses. In certain contexts it may be a very conservative claim that economic analysis is bad because it has the power to change the way we view something.

My claim is that gender equality requires us to take the economics of home labor seriously. This argument turns on a comparison between wage labor and home labor, which are similar both in content and in many of the motivations

3. Tuming Labor into Love also compared the singularity of viewpoint about domestic labor among courts and legislators to the understandings of home labor in the fields of economics and sociology. In those fields, the home was once understood as an unproductive site of either consumption or emotions. But in recent years, a shift has occurred in each field toward understanding the home as a place of economically productive activity. That shift in other disciplines has allowed for entirely new research questions to be raised and explored in those fields, and I argued that law would benefit from the same shift in understanding. Id. at 15-21.

4. The discourse is by no means limited to women's experiences. Richard Titmuss, for example, studied markets and altruism in blood donation. RICHARD TITMUSS, THE GFT RELATIONSHIP: FROM HUMAN BLOOD TO SOCIAL POLICY (1971). Margaret Jane Radin has criticized the commodification of housing and employment. See Margaret Jane Radin, Market-Inalienability, 100 HARV. L. REV. 1849 (1987). But the most sustained critiques have been in areas touching on women's experience.

5. See Nancy C. Staudt, Taxing Housework, 84 GEO. L.J. 1571 (1996) (addressing commodification concerns with her effort to quantify the value of home labor for taxation purposes); see also Blumberg, supra note 1; White, supra note 1 . I heard the commodification critique every time I delivered a talk based on the draft of Tuming Labor into Love and in correspondence since its publication.

6. See MARGaret JANE RADIN, CONIESTED COMMODIIES 104 (1996)

7. Id. 
that drive workers. I argue that the difference in the treatment between them may be difference based on gender. I discuss the tendency to raise commodification concerns when women's interests are at stake, and question whether resistance to market reasoning in these contexts is a form of resistance to women's economic power. I then examine some legal doctrines touching on home labor that could benefit from economic analysis. If importing economic reasoning into these areas transforms our understanding of them, I posit that women would benefit from that transformation. I conclude that as long as so many of women's activities remain non-market and as long as women's economic welfare is a concern of feminists, economic analysis of non-market activities is affirmatively desirable. My objective is to show what can be gained by allowing economics to inform, without dominating, the discourse on policy and doctrine surrounding home labor. Concern over women's lives becoming entirely commodified seems by comparison an abstract worry.

\section{The COMMOdIFICATION ObJECTION: SETTING OUT THE CASE AGAINST ECONOMICS}

\section{A. The Basic Problem with Commodification}

The standard argument against commodification, often referred to as the "commodification critique," is that certain human attributes or certain resources should lie wholly or partially beyond exchange, because to allow exchange would be inconsistent with a vision of personhood or human flourishing. Prohibiting exchange may not be enough; it may be necessary to discourage economic analysis and discourse about these attributes. "[M]any kinds of particulars-one's politics, work, religion, family, love, sexuality, friendships, altruism, experiences, wisdom, moral commitments, character, and personal attributes [are] . . integral to the self. To understand any of these as monetizable ... is to do violence to our deepest understanding of what it is to be human."

Elizabeth Anderson has reviewed commodification concerns and applied them to women's reproductive labor in a piece interestingly titled, "Is Women's Labor a Commodity?" She defines a commodity as something to which "the norms of the market are appropriate for regulating its production, exchange and

8. Radin, supra note 4 at 1905-06. The commodification literature is far too expansive to review in detail here, particularly given my narrower concern with domestic labor. See, e.g., ELZABETH ANDERSON, VALUE $\mathrm{N}$ ETHICS AND ECONOMICS (1993); MARTHA NUSSBAUM, LOVE's KNOWLEDGE (1990); HILARY PUTNAM, REASON, TRUTH AND HISTORY (1981); RADIN, supra note 6; MichaEl WALTZER, SPHERES OF JUSTICE: A Defense of PluRalism and Equality (1983); James B. WHITE, Heracles' Bow (1985); Elizabeth S. Anderson, Is Women's Labor a Commodity? 19 PHIl. \& PUB. AFF. 71 (1990); Neil Duxbury, Do Markets Degrade? 59 MOD. L. REV. 331 (1996); Milton C. Regan, Jr., Market Discourse and Moral Neutrality in Divoree Law, 1994 UTAH L. REV. 605 (1994); White, supra note 1.

9. See Anderson, supra note 8. I find the title interesting because she uses the seemingly broad term "women's labor" although she purports to be discussing only surrogate motherhood. The broader title may reflect just the gender perspective on all women's activities that 1 criticize in Section III.C.2. See also ANDERSON, supra note 8, at 168-89. 
enjoyment." ${ }^{\text {"10 }}$ The application of market norms is inappropriate where they "fail to value [the thing] in an appropriate way."11 If it is appropriate to apply "use" as the proper mode of valuation, then market norms are acceptable and we may treat something as a commodity. ${ }^{12}$ If instead, a mode of valuation such as respect, "love, admiration, honor and appreciation," we should not treat something as a commodity. To value something differently than as a commodity is, according to Anderson, to recognize a "special intrinsic worth" to that item. ${ }^{14}$ This essentialist notion that things have an intrinsic worth turns out to be important to anti-commodification arguments. ${ }^{15}$ Anderson argues, "When women's labor is treated as a commodity, the women who perform it are degraded." ${ }^{\text {"16 }}$ Degradation means that "something is treated in accordance with a lower mode of valuation than is proper to it."17 Finally Anderson believes that commodifying women's labor leads to exploitation of women. This is so because women's noncommercial motivations are taken advantage of without offering anything but commercial responses. ${ }^{18}$

Anderson's work draws on a notion of incommensurability of value that is seen in the work of Martha Nussbaum. ${ }^{19}$ As applied to the domestic labor context, the problem of incommensurability would arise with the need to give the labor a market value when it is not commensurable to market goods or services. They may not be commensurable where, for example, one is measured on a valuation scale that can translate into dollars, where another is measured on one that cannot, such as love, admiration, wonder, or respect. While these scholars have not applied their critiques directly to housework, it can be argued that there is no perfectly accurate market replacement for unpaid work, for example childcare, that a family member performs.

The commodification critique applies to an analysis of the economy of the home and the family labor that occurs there, as well as to the actual purchase and sale of that labor. To Anderson, market norms have an "expressive significance" as well as a practical one, and can thus infect non-market conceptions of women's labor. ${ }^{20}$ The argument posits that talk matters: you can pervert the personalness of something by talking about it as if it were fungible. Identifying an "economy," meaning a set of implicit valuations and exchanges, is possible even where "real markets" are either prohibited or practically impossible to

10. Anderson, supra note 8, at 72 .

11. Id.

12. See id.

13. Id.

14. See id. at n.2.

15. Later, when comparing home labor to wage labor, I will question whether it can be meaningfully said that the difference between the two is in any sense intrinsic

16. Anderson, supra note 8, at 75.

17. Id. at 77. By this she means that a use valuation is applied to it, when, for example, the mode of valuation should be a higher form such as admiration, respect, or love.

18. See id. at 81 .

19. See NUSSBAUM, supra note 8, at 106-24.

20. See Anderson, supra note 8 , at 77. 
imagine: organs for transplantation, sexual contacts, candidates for marriage partnerships, religious convictions, love, or a person's politics. Although in many cases this is just talk, ${ }^{21}$ to a commodification skeptic, that talk itself does damage to the integrity of the attribute in question: sexuality, love, marriage, health. ${ }^{22}$

James Boyd White has made this case most powerfully, arguing that expression is never transparent, but instead constitutes and transforms the reality it describes. Says White: "the languages we speak, and the cultural practices they at once reflect and make possible, form our minds by habituating them to certain modes of attention, certain ways of seeing and conceiving of oneself and of the world."23 White concludes that economic language should be "vigorously resist[ed]"24 because "[t]he conventions of this discourse necessarily habituate its user[s] to thinking in terms of self-interest as a central principle." ${ }^{25}$ In passing, he applies this critique to an economic understanding of home labor, noting that:

The segmentation of the exchange model tends to misvalue the work we do for ourselves, which is most of the traditional work of women ... . This is especially true of people who raise their own children. Such work cannot be segmented into functions and then made the material of the market process, actual or hypothetical, for what the child requires is the sustained presence of, and interaction with, a loving and respectful person, something no alternative can supply. Similarly, housework has a different meaning when one is maintaining one's own home rather than acting as a servant for others. ${ }^{26}$

To those who see a difference between real and rhetorical markets, the difference tends to be treated as one of degree. Under this view, it might not hurt personhood as much to talk about markets in certain attributes as it does to create such markets, but talk certainly doesn't help. By condemning talk as well as trades, skeptics take away the opportunity to make the affirmative case for the benefits of an economic perspective. For legal analysts, this conflation of actual buying and selling and market analysis proves problematic, as we will see later.

\section{B. A Taxonomy of Anticommodification Discourse}

Margaret Radin sets out a number of useful categories of thought about commodification. She uses the term "radical non-commodification" to refer to a

21. In some cases, it is not just talk. For example, prostitution, whether legally sanctioned or not, is widespread, and there is an underground market in foreign brides.

22. This point is made by both Radin and Anderson. See Radin, supra note 4, at 86-88; Anderson, supra note 8 , at 77 .

23. White, supra note 8 , at 166.

24. Id. at 164 .

25. Id. at 173-74.

26. Id. at 190 . 
utopian vision in which people and things are embodied with unique personality and cannot be exchanged under any circumstances. ${ }^{27}$ The ideal of universal noncommodification is associated with Marx, and arguably lurks in the background of Radin's early work, which idealizes a future world without commodification but acknowledges the distance between this world and that one. Radical commodification describes an ideal where anything of value will be ownable and freely exchangeable. ${ }^{28}$ Radical commodification within the legal discourse is associated with Gary Becker and Richard Posner. ${ }^{29}$ To them, it is often said, every objection to markets other than on administrability grounds is misguided, mushy sentimentality that hurts the people it is intended to help. Real welfare, both individual and societal, will always be promoted by permitting exchange. Nothing is off the table: babies, ${ }^{30}$ organs, ${ }^{31}$ surrogacy, ${ }^{32}$ sex,${ }^{33}$ justice, ${ }^{34}$ and so on.

Finally, "partial commodification" describes Radin's understanding of our current world. She uses employment law and housing market regulation as examples, because both are traded in the market but that trade is subject to extensive regulation. ${ }^{35}$ Radin points to ways in which the idea of partial commodification can be used. ${ }^{36}$ First, we might have spheres of commodification, where some areas of experience are inappropriate for commodification altogether, but those things that can be commodified are commodified completely. Radin calls this "liberal compartmentalization," identifies Michael Walzer as its most distinguished proponent, and disapproves of it as both impossible and undesirable. ${ }^{37}$ Liberal compartmentalization is most clearly illustrated by the desire to establish the home and the political sphere as spaces that are entirely non-market, with much of what is outside of the home and the government as presumptively a market domain. This kind of partial commodification is one way to remedy the uneasiness most people have with

27. See RADN, supra note 6, at 79-83.

28. Posner takes the view that as long as it is administratively feasible to have a market, there should be one for everything that people value that is also scarce. See RICHARD A. POSNER, ECONOMIC ANALYSIS OF LAW 32-35 (4th ed. 1992); see also Richard A. Epstein, Why Restrain Alienation? 85 CoLUM. L. REV. 970 (1985).

29. Gary S. Becker has earned this reputation through A TREATISE ON THE FAMILY (1981), his Nobel Prize winning work. Posner has earned this reputation based largely on an article proposing a market in adoption and his economic analysis of sex and sexual regulation, SEX AND REASON (1992). Whether these reputations are an entirely accurate reflection of the work is not important to this argument: they both serve as place-markers in the discourse on commodification within legal academics.

30. See Elisabeth M. Landes \& Richard A. Posner, The Economics of the Baby Shortage, 7 J. LEGAL STUD. 323 (1978)

31. See Lloyd R. Cohen, Increasing the Supply of Transplant Organs: The Virtues of a Futures Market, 58 GEO. WASH. L. REV. 1 (1989).

32. See Comments, Baby-Sitting Consideration: Surrogate Mother \$ Right to "Rent Her Womb" for a Fee, 18 GoNz. L. REV. 539 (1983).

33. See generally POSNER, supra note 29.

34. See Gary S. Becker \& George J. Stigler, Low Enforcement, Malfeasance, and Compensation of Enforcers, 3 J. LEGAL STUD. 1 (1974).

35. RADIN, supra note 6 , at 108-110.

36. See id. at 46-53, 102-I18.

37. See id. at $46-53$. 
radical commodification. Radin dislikes it because it permits unfettered commodification in those areas that do not receive complete market immunity. ${ }^{38}$ I dislike it because it permits unfettered noncommodification of large segments of women's labor, as I will argue later.

The other kind of partial commodification is called "incomplete commodification" by Radin, and she believes that it provides a better descriptive and normative view. ${ }^{39}$ Incomplete commodification applies where the same attribute or thing is thought of in both market and non-market terms. There are no spheres where the market is completely banished or completely dominant. Competing market and non-market conceptions of the same thing can be held in two ways. The first is by different segments of society who contest either the commodified or the non-commodified understanding held by others but where neither segment can claim a consensus. The second is where a person or people understand both the commodity aspects of a thing or attribute and its noncommodity aspects; here the two understandings are simultaneously at work within the same person. Radin says that both of these types of co-existences have led to public policy choices that embody or accommodate the plural meaning at play. Radin argues that these multiple meanings can achieve stability, and when they do we are better off than if we require one conception to extinguish others. She is particularly concerned with making sure that market understandings do not extinguish non-market ones. ${ }^{40}$

Radin identifies what she calls the "domino theory" in the discourse on commodification. ${ }^{41}$ This is the idea that is held by many that if any commodified version of an attribute or thing exists, non-commodified versions will cease to exist. Where incomplete commodification exists, the market understanding will eventually prevail over the non-market understanding, and the non-market understanding will be extinguished. While the inevitability of extinguishing nonmarket understandings is never well-explained, the argument is used to support prohibitions on all commodification of an activity. For example, if it is important to the culture that a non-commodified version of sexuality exists, and if any commercialized sexuality will extinguish or infect the non-commodified version by making all people understand their sexuality as having a price, all commercialized sex must be prohibited to honor the greater societal value placed on the continued existence of non-commodified sex. The domino theory posits that both cannot exist without changing each other.

Another example of the domino theory argument is one against surrogate mothering or markets in adoption. These arguments proceed as follows: it would be awful for children to understand themselves as having a price. If any children are traded through the process of surrogacy or markets in adoption, all children

\footnotetext{
38. See id. at 46 .

39. See id. at 102-118.

40. See id. at 107.

41. See id. at 95-101.
} 
will come to understand that they too are marketable. This understanding would extinguish the non-market norm in familial relations. ${ }^{42}$ Since the latter norm is extremely valuable to us, we should not allow any commodification of either reproductive capacity or adoption, lest the non-commodified conception cease to exist even in that majority of cases where markets played no role in the formation of a family. ${ }^{43}$

Radin identifies what she calls the problem of the double bind: one might idealize non-commodification in a utopian world, but in this world decommodifying only certain things may do more harm than good. ${ }^{44}$ For example, total decommodification of sexuality may be an ultimate goal, but as long as it is partially commodified, prohibiting prostitution may do more harm than good by hurting a particularly vulnerable class of people: those engaged in the commercial sex industry. She calls this a problem of transitional balancing, where the transition is from our world to an ideal world. ${ }^{45}$ The balancing trick is to consider the damaging effects of non-commodification in the present world and thus tend toward permitting commodification, while also considering the domino effect whereby commodifying might change the nature of the thing for the worse, so that we find ourselves moving farther from the ideal. How to decide between these two pulls of the double bind? Says Radin, there is no formula. We must engage in a context-specific, factual inquiry to tell us whether commodification or decommodification will do more good than harm, all things considered, for each given contested attribute or thing. Her formula gives us no real criteria for making the decision, but it does invite us to go straight to the facts and not to force the conversation onto a broader theoretical plane.

The idealized future world in Radin's view seems implicitly to be one without commodification, ${ }^{46}$ but she has become increasingly open to the limited use of markets and market language in contested cases. Although it contained many qualifications and examples of partial commodification, her earlier work on the subject, most notably Market-Inalienability, ${ }^{47}$ left the legal academy with

42. See, e.g., Anderson, supra note 8, at 77-78 (taking this view of the expressive function of sales that can spill over into non-market activities).

43. A final classic example of the domino theory is blood donation. See generally RicharD M. TrTMUSS, THE GFT RELATIONSHIP: FROM HUMAN BLOOD to SOCIAL POLICY (1971). Titmuss argues that people donate blood because they understand themselves to be doing an act of generosity that is literally and figuratively priceless. If blood were routinely bought and sold, as it has been at some times and in some places, the priceless act would acquire a relatively low market value. Knowing that blood could simply be bought in a shortage, people would no longer feel either the urgency to give or the satisfaction at having done something heroic. Donors, it is argued, are less likely to endanger the blood supply than those who sell blood, and thus a market in blood would both harm the blood supply and take away the opportunity for altruism that blood donation currently provides. Where both a market and a non-market version exist, the market version extinguishes the viability of the non-market version. If the non-market version is more important, the argument goes, the market version must not be permitted lest we lose the better version. Id.

44. See RADI, supra note 6, at 123-130.

45. See Radin, supra note 4, at 1875.

46. I say implicitly because Radin is careful not to make this claim fully, although it is thoroughly implicit in Market-Inalienability, supra note 4, and continues to be relevant in CONTESTED COMMODIIES, supra note 6.

47. Radin, supra note 4. 
the overall impression that she was arguing that any commodification, rhetorical or real, begins us on a long slippery slope to the undesired end of universal commodification. Her most recent work, Contested Commodities, ${ }^{48}$ leaves a different impression. She argues that there are many ways in which partial commodification can thrive and remain stable. Her taxonomy of commodification there, where she discusses what she calls "plural meaning,"49 is very useful in thinking about domestic labor, as we will see below. Because it is such an integral part of the response to commodification critiques, I devote Part III, Section A to a discussion of plural meaning.

Ultimately, however, Radin makes a one-way claim for the value of importing non-market understandings into market activities. She believes that improvement of personhood will come from a better grasp of those non-market attributes. I thoroughly agree with Radin's conclusion that multiple conceptions are possible and beneficial, but my emphasis for this paper is to turn her conclusion around. I argue for a better recognition of and understanding of the economic aspects of non-market activities. Under this view, plural meanings are not a matter of transition; either market or non-market understandings are functional representations, not ideal models.

\section{Feminism and Economic Skepticism}

Feminists rank high among those who are skeptical of economists. This skepticism proceeds on two fronts in the domestic labor context. The two parts are a negative reaction to economics as a way to describe home activities, and an affirmatively positive response to love and affections as a descriptively accurate way of understanding and explaining productivity in the home.

\section{Offense at Economics}

Some feminists have a visceral dislike for economic analysis. While there are many reasons for this, I believe two are most strongly at play. The first is situational: Many feminists don't trust the current practitioners of economic analysis. The second is more substantive: Many feminists do not accept the implicit notion of fungibility at play in economic analysis.

The problem of distrust may come from two characteristics of economic discourse. The first is a driving, relentless essentialism among economists. Much economic literature reads like much more than a useful tool with which to explain certain phenomenon. It instead reads like the raison d'être of that phenomenon, its beginning and end. Everyone has her favorite example of a social phenomenon being mercilessly pushed into an economic model producing

48. RADIN, supra note 6 .

49. See id. at 102, 107. 
logically clean but absurd explanations: adoption, ${ }^{50}$ marriage, ${ }^{51}$ heroic rescues, ${ }^{52}$ voting, ${ }^{53}$ altruism, ${ }^{54}$ religion, ${ }^{55}$ childbirth, ${ }^{56}$ sexuality. ${ }^{57}$ This kind of relentless essentialism among economists ${ }^{58}$ leaves reasonable people with what appears to be a decision to either embrace the whole absurd end of the spectrum or jump ship entirely. I will argue that it is fully possible and desirable to use economics to assist in understanding a social phenomenon without turning away from other possible explanations or understandings. But this does not describe much of the dominant economic analysis practiced in the legal academic community. The idea of extending this sort of essentialism into the social relations surrounding family labor seems to carry the risk of damaging the complex context of dependencies and moral and emotional commitments made there.

The second reason many feminists distrust practitioners of economic analysis is that they often employ assumptions with suspect origins. Moreover, although these are almost always identified at the outset as assumptions, by the end of the equation they seem to have assumed the status of fact. In legal discourse, when an assumption is used in an economic model, we usually see the burden of proof implicitly shifted to critics of the model to disprove the factual assumption despite the frequent lack of evidence in favor of the assumption from the outset. There is the well-known joke about the economists on a desert island with a case of food in tin cans. They begin their plan for opening the cans by saying. "First, let's assume a can opener." It's funny when it's a can opener. It is not so funny, or at least it shouldn't be, when the empirically unsupported assumption is that women want children more than men do, that women have higher inherent value when they are young and men are worth more when they are older, ${ }^{59}$ that husbands and wives in most cases have the perfect trust and agency necessary to treat them as a single economic unit (individuals are selfish and self-interested but family heads are altruistic) ${ }^{60}$ or that rapists would pay for sex somehow if they had the necessary wealth of money, power, or looks themselves. ${ }^{61}$ Having

50. See Landes \& Posner, supra note 30.

51. See BECKER, supra note 29.

52. See Elisabeth M. Landes \& Richard A. Posner, Salvars, Finders, Good Samaritans, and Other Rescuers: An Economic Study of Low and Altruism, 7 J. LEGAL STUD. 83 (1978).

53. See POSNER, supra note 28.

54. See BECKER, supra note 29 , at $194-95$.

55. Comment, Schylla, Charybdis, and Adam Smith: An Economic Analysis of the Religion Clauses, 39 DE PAUL L. REV. 1235 (1990).

56. Stephen V. Marks, Teaching Guide: Abortion Economics, 26 EcONOMIC INQUIRY 175 (1988).

57. See POSNER, supra note 29.

58. I think here particularly of Gary Becker because his work deals so directly with women's issues. This by no means describes all economists. See, e.g., DONALD N. MCCLOSKEY, THE RHETORIC OF ECONOMCS (1985). However, it describes enough of the literature to account for a general aversion to economic analysis on this ground.

59. Lloyd Cohen, Marriage, Divorce, and Quasi-Rents, 16 J. LEGAL STUD. 267, 285-86 (1987) (arguing that the ability to bear children raises women's value, as does youthful beauty).

60. See BECKER, supra note 29, at 172-201.

61. See POSNER, supra note 28 , at 201 (using rape as an example of coerced wealth transfer). 
those assumptions implicitly raised to the level of facts over the course of an economic analysis is particularly problematic.

I think of the implicit elevation of assumption to fact as "assumption slippage." It must be noted that this slippage is a dynamic process: Readers of economic texts, particularly in the legal community, are participants in its occurrence as much if not sometimes more than economic authors. Much of the most prominent economic analysis of family and gender relations, particularly that associated with Gary Becker, relies on very questionable assumptions that appear to come right out of the pages of The Total Woman ${ }^{62}$ and from there they help to build economic rationalizations for very conventional mid-twentieth century middle class suburban gender relations. ${ }^{63}$ In the words of Barabara Bergmann, "to say that New Home Economists [Becker et al.] are not feminists in their orientation would be as much of an understatement as to say that Bengal tigers are not vegetarians. ${ }^{264}$ Isabel V. Sawhill has offered a critique of the lack of empirical basis for some of the basic assumptions of the New Home Economists who are prominent in the field. ${ }^{65}$ As economists know from their training but their legal readers quickly forget, an economic model is only as good as its assumptions. Hence, the implicit standard in economic scholarship is that unproved assumptions must be plausible before a model based on them is acceptable, even with caveats. In the context of home labor, those assumptions are very important. Assuming altruistic heads of households reduces the need to worry about disparate human capital investments made within the family. The assumption that women desire children more than men do provides an explanation for what otherwise might be tricky distributional results that occur within families. If these are to be the assumptions on which an economic analysis of home labor is to proceed, many people do not want any part of it.

I cannot join the routine conclusion that the problems with Gary Becker's work are so far-reaching as to make his work as a whole of limited use. We are indebted to Becker for raising extraordinarily important economic questions about the functioning of the family. Becker has brought us many ideas that are extremely helpful in thinking about family relations, including the very notion that in economic terms the home is a place of production and not just a place of consumption. If he has proceeded from unsupportable or incomplete assumptions, those can be corrected and the analysis and its outcomes adjusted

62. MIRABle MORgan, THE TOtal WOMAN (1973). This text served as a guide to Good-Wife behavior in an effort to protect conventional middle class marriage from the social unrest caused by second-wave feminism.

63. Nobel-Prize-winning economist Gary Becker is the most prominent among these economists, but he has many followers. An example is Becker's calculation that women have a comparative advantage in childrearing that explains the division of labor whereby men engage in market activities and women engage in non-market activities. See BECKER, supra note 29, at 21-32.

64. Barbara Bergmann, The Task of a Feminist Economics: A More Equitable Future, in THE IMPACT OF FEMINIST RESEARCH IN THE ACADEMY,132-33 (Christie Famham ed., 1987).

65. Isabel V. Sawhill, Economic Perspectives on the Family, 106 DAEDalus 115, 120-24 (1977). Others have followed. See generally BEYOND ECONOMIC MAN (Marianne A. Ferber \& Julie A. Nelson eds., 1993). 
accordingly. Indeed, examining and critiquing these assumptions has been a large implicit part of the feminist response to law and economics already, and should continue to be so. However, critiquing assumptions does not inflict a fatal blow to methodology. It would be a mistake to hold these questionable assumptions out as an indictment of an entire mode of analysis. This is a standard to which most scholars would not wish to be held, and feminists are no exception.

There is, however, an extremely important lesson about the scope of the usefulness of economic analysis to be learned from assumption slippage and the response to it: empiricism counts. Empirical research and data need to drive any real search for policy solutions to basic problems, or even to clear understandings of the problems themselves. Law professors are not in a great position at this time to do empirical research and must rely on fields outside of law or economics, such as sociology, to inform economic understandings. Doing so is not without its own difficulties for lawyers untrained in understanding and sorting sociological research. The most that economic understandings can do is to highlight some empirical questions that need to be answered. Even answers to empirical questions do not close debates over facts. If we are confident that a resource is scarce as a matter of empirical fact, we can either treat that as a given or instead ask why it is scarce. That which has an empirical basis is not thereby natural or inevitable, and so even provable assumptions should be open for wellframed criticisms. But once again, economics can assist in the framing task itself.

I do not wish to be understood as overstating the ease of remembering that we are dealing with hypothetical models when we use economic analysis. I think the risk of forgetting is more serious when we cannot verify the empirical assumption. We move quickly on from it, sensing that the unavailability of data threatens to make an otherwise elegant model useless. Perversely, the less supportable an assumption, the less contestable it is, and the more it acquires the status of fact. It may be that James Boyd White's concern with the culture of economic discourse is played out most seriously when data is least available.

The next level of concern over economic analysis does not center solely on the supposed "priors" of its practitioners. It is a more substantive criticism: A rejection of the suggestion that many attributes of family life and work are fungible, and thus that the study of value can proceed by observing choices people make. Fungibility is the idea that goods, services, or attributes can be placed on a single metric of value and then traded off against one another on that metric. Fungible things can be replaced by something else that falls in the same place on the metric, such as similar services by a different person, or simply money measured in the right amount, without regret. On this account, economics is entirely concerned with theoretically measurable maximized choice among alternatives, rather than being concerned with the personal experience of choice, methods of provisioning in general (whether by voluntary exchange, gift-giving, 
or coercion), ${ }^{66}$ or with the process of developing what economists call preferences. Radin concedes that whether we think the fact of choice between alternatives proves fungibility, as many economists believe, or instead prove nothing about fungibility, is largely a matter of intuition. ${ }^{67}$ Joseph Raz argues that the meaning we give to a choice is its conventional understanding, and if that does not include a trade along a single metric, then no such fungibility can be inferred. ${ }^{68}$ Raz taps into many people's response to the talk of fungibility when thinking about marriage, romantic partners, and family work choices that are implicit in an economic analysis of home labor.

There is a similar negative response to the notion of bargaining within marriage or within family relations, which is an important element of an economic understanding of home labor. Though a bargaining model is often thought of as an improvement on Becker's notion of an altruistic head of household which can justify a failure to examine interspousal conflict, the bargaining model itself draws a negative response from many. ${ }^{69}$ While many would acknowledge much day-to-day bargaining within the family, it is also thought that a bargaining analysis fails to capture the altruistic behavior layered alongside self-interested behavior in family relations. It is difficult to predict much about behavior if one can rely neither on complete self-interest nor on complete altruism, and a bargaining analysis of family labor puts forward assumptions about family behavior to which many respond negatively. ${ }^{70}$

\section{The Aptness of the Emotional Understanding}

The former critique, that family labor is not fungible and not always strategic, is also frequently stated in the affirmative: Family labor is uniquely emotional. In Turning Labor into Love, I bring an operative mode of analysis to the surface-home labor is viewed as an expression of familial emotions. In discussing this argument with others, I would routinely hear that this is the mode of analysis at play in law because it is an accurate characterization of family behavior. What is wrong with the affections characterization? Family care is all

66. See Julie A. Nelson, The Study of Choice or the Study of Provisioning?: Gender and the Definition of Economics, in BEYOND ECONOMC MAN 23 (Marianne A. Ferber \& Julie A. Nelson eds., 1993).

67. See RADIN, supra note 6, at 12.

68. See Joseph Raz, Value Incommensurability: Some Preliminaries, 86 PROCEEDINGS OF THE ARISTOTELIAN SOCIETY 117, 128, 132-34 (1985-86).

69. See Marilyn Manser \& Murray Brown, Marriage and Household Decision-Making: A Bargaining Analysis, 21 INT'L ECON. REV. 31 (1980).

70. A bargaining analysis assumes complete self-interest as between spouses, an assumption that is probably no more plausible than one of complete altruism. See Paula England, The Separative Self: Androcentric Bias in Neoclassical Assumptions, in BEYOND ECONOMIC MAN, 37, 48 (Marianne A. Ferber \& Julie A. Nelson eds., 1993). In Rational Fools: A Critique of the Behavioral Foundation of Economic Theory, 6 PHIL. \& PUB. AFF. 317 (1977), Amartya K. Sen first made this point about the limitations of economic thinking after one drops the implausible assumption of purely self-interested human behavior. Game theorists have identified this general issue in recent years through discussions of co-operative or partially co-operative models, which might usefully be applied to family decision-making. Nonetheless, economists have not perfected a response to this important criticism. 
about affections. Should courts ignore the emotional motivations behind caring for a child or preparing a meal for a partner or spouse? While I will argue below that this idea can co-exist with an economic understanding of home labor, many feel that an economic understanding demotes or denigrates the emotional significance of home labor: this is the essence of the domino theory at play. These criticisms of the commodification of home labor through the use of economic rhetoric and analysis, in many general respects, represent a subset of criticisms of all commodification and economic rhetoric. The family context, however, raises the concerns discussed above in a particularly bright light.

I believe that feminist skepticism of economics is understandable but should be avoided. I will argue below that keeping economic understandings away from women's activities represents a particularly gendered understanding of those activities that is itself costly.

\section{A REPLY}

My response to the critiques set out so far is that the feminist legal discourse should be open to economic understandings of home labor. The argument proceeds on several fronts. First, a claim for economic understandings is not a claim against other understandings. Here I build on Radin's idea that phenomenon have plural meanings. ${ }^{71}$ Next, within legal discourse, the transformative effect of language may not operate with the all-consuming power that some might expect from language in other areas of study. Furthermore, to the extent that economic analysis has the transformative power that skeptics of economics attribute to it, I question the general assumption that these transformed norms are inherently negative if they highlight market understandings. I do so by examining the case of home labor. I argue that home labor and wage labor are in many ways similar. That similarity includes both the content of the work and the mixed motivations behind the work. Both waged and unwaged labor contain market and non-market aspects. I posit that differences between their treatment ought to be understood as differences related to gender, given the history and current practices surrounding home labor. I ask for skepticism toward that different treatment, given its tendency to leave women without cash in the name of non-commodification. I explore the tendency of the non-commodification argument to be economically disempowering to women in other areas in support of the claim that it has this effect on home labor. I then return to the claim that transformation of current understandings is not always a ground for criticizing language, and that in the home labor context, it may be a ground for embracing economic language. I end with a set of policy debates that I believe can be enhanced by viewing home labor as economic activity.

71. See RADIN, supra note 6, at 102-114. 


\section{A. Plural Meaning}

The most important response to the commodification critique, and one that Radin herself embraces, is the notion of what she calls "plural meanings:" multiple understandings of a single activity that can co-exist. ${ }^{72}$

The way to a less commodified society is to see and foster the nonmarket aspect of much of what we buy and sell, to honor our internally plural understandings, rather than to erect a wall to keep a certain few things completely off the market and abandon everything else to market rationality. ${ }^{73}$

While Radin's insight into the possibility of plural meaning is useful, it is impossible not to notice her hierarchy among models. She seeks a less commodified society, not plural conceptions of human activity. Radin gives little encouragement for us to bring out the market aspects of non-market activity such as home labor. Her claim falls short of being for a richness of understanding that includes economics as itself one creative force in personality. I hope to make the claim for that possibility by bringing forward some of the negative aspects of non-market understandings. I wish to do this while maintaining the notion that neither an economic nor an emotional understanding of non-market activities is intrinsic to the activities themselves. This latter point saves room for Radin's desire to promote plural meaning, but it rests less on an implicit trajectory toward an ideal of a singular, and for her non-market, conception.

Suppose human activity is multifaceted and will resist any singular, encompassing description. Home labor, as with so many human activities or attributes, cannot be understood entirely with economic reasoning. Economic reasoning, however, can be one of several ways to interpret human activity that will show us a facet of that activity and enrich our understanding of it. We probably experience many things as such; the question is whether we are able to highlight that experience. While this point might be raised by a critic of economics because of the tendency among some economists to be essentialist in their thinking, it also should rescue economic analysis for those who would banish it entirely from legal discourse. If the problem is a lack of nuance among economists, feminists should not employ a similar lack of nuance by rejecting economic reasoning or, as in Radin's case, looking for its gradual demise.

Radin asks if we can both know the price of something and simultaneously know that it is priceless. ${ }^{74}$ I believe the answer is yes. An important illustration of this point can be found in Viviana Rotman Zelizar's historical examination of

\footnotetext{
72. See id.

73. Id. at 107

74. See id at 101.
} 
the life insurance industry. ${ }^{75}$ In the first half of the nineteenth century there was tremendous public resistance to the sale of life insurance in the United States because the public took offense at the suggestion that a life could be valued in monetary terms. ${ }^{76}$ The insurance industry responded to the resistance with a pitch that was aimed at the idea that the life was not worth the money. Widows needed to be cared for after the death of a spouse, and insurance would help with that, although it would in no way replace the life lost. ${ }^{77}$ Under this conception, the life insurance market took off. ${ }^{78}$ Today's life insurance market does not offend most people on commodification grounds, despite its known actuarial focus. ${ }^{79}$ Life insurance is considered a kind and responsible purchase for family members, who do not thereby come to view the insured loved one as bearing a price. Students of insurance would argue that it is not about pricing life at all but about subjectively chosen levels of risk. Thus, a "price" does not unseat the understanding of pricelessness. The fact of a price does not create a market: we would not accept the argument that since we price lives for insurance purposes, we may also buy and sell people. Such an idea would only serve to show us that the "price" does not capture the value. It instead serves a limited purpose that is unrelated to real value.

Radin makes the interesting point that by promoting the exile of economic understandings entirely, we implicitly grant too much power to that mode of analysis. ${ }^{80}$ If we believe that the very existence of an economic discourse destroys other understandings of the same phenomenon, we grant that economic discourse has become a baseline that will always extinguish other understandings if it is permitted to thrive. ${ }^{81}$ Elizabeth $\mathrm{S}$. Anderson's analysis displays this belief. ${ }^{82}$ That economics need not extinguish other perspectives will be an important idea when thinking about the potentially important emotional perspective on family labor.

Economics is a tool for identifying the allocational issues at play in a given social setting. ${ }^{83}$ An important implication of Radin's notion of plural meaning is that where a plural or multifaceted understanding is employed, policy and legal choices can be made that embody those plural understandings. This should be important when thinking about the policy issues surrounding home labor. I argue that the addition of some understanding of the economic significance of home

75. See Viviana Rotman Zellzar, Morals and Markets: The DeVElopment of LifE INSURANCE IN THE UNITED STATES (1979).

76. See id. at $1-5,41-46$.

77. See id. at 94-96.

78. See id. at 6-7, 102-105.

79. Some of the socially accepted understandings of life insurance may recently have become contested as a result of the AIDS epidemic.

80. See RADIN, supra note 6 , at 103.

81. See id.

82. See Anderson, supra note 8, at 87-89.

83. This is so even if, as White argues, "tools" are not themselves simple. See White, supra note 1 , at 166. 
labor, without moving it into an unregulated market, would positively inform - legal discourse on the home.

Anderson is concerned that commodification of women's labor leads to the exploitation of women because it gives only a commercial response to women's noncommercial motivations. ${ }^{84}$ Anderson's analysis does not account for the possibility of women's mixed motivations, or at minimum her analysis clearly privileges the non-market motivations. Anderson's analysis also does not allow for the possibility that responses that are noncommercial may exist even where commercial responses exist.

Consider the benefits gained in the fields of sociology and economics from a shift in understandings of home activity. ${ }^{85}$ Before either field had made the transition from seeing the home only as the site of consumption and affections to seeing home activity as work, neither field had the occasion to ask the questions that arise from that observation: what is this work like? Is it safe, efficient, stressful? What are its standards and practices? How does it compare to market work in terms of needed human capital development, productivity, and job satisfaction? We ought to care very much about the answers to these questions. The questions were not available to the eye of the economist or sociologist until the notion of work was imported into the home. Legal analysis is very much in need of the same opening of questions.

\section{B. The Limited Influence of Talk in Legal Discourse: Plural Meaning as the Norm}

Does talking about home labor as productive mean commodifying it? It becomes important to think about what is meant by commodification. To assume that there is no important difference between analyzing the economics of something and creating an unregulated market for that same thing is terribly damaging to intellectual discourse. "Wages for housework" is not the only possible outcome of this exercise. Even if there is only a difference of degree between talk and real markets, as the commodification literature suggests, that difference should matter for the purposes of legal analysis.

Rhetoric and real markets differ particularly in the legal context. We routinely ask questions about value in legal practice as if a market exists where one does not. Consider the wrongful death suit or any tort suit that includes a claim for pain and suffering damages. The value of these claims is obviously not established by a real market. Moreover, it is not difficult for most people to accept that there should not ever be a real market in these things. Nonetheless, in a tort action, we allow money to change hands as if a market value were placed on these things. Cass Sunstein identifies this as "as if" reasoning. We think of damages "as if" they could be marketized, but at the same time we know that

84. See Anderson, supra note 8 , at 81 .

85. See Silbaugh, supra note 2, at 15-21, for an extended discussion of this point. 
they cannot ${ }^{86}$ This is a clear practical example of the existence of what Radin calls plural meanings.

Monetization of things for which there is no market and no push for a market for the purpose of providing a remedy within the law is an illustration of the resilience of non-market conceptions. While legal academics may fret about the message we are sending by placing a value on the loss of an arm, the non-legal world does not appear to have been influenced into believing that arms are worth an $x$ sum of money, despite the many years that a monetary remedy has been provided for the loss of an arm. Loss of consortium damages are an even better example of this phenomenon. This routine fact of legal discourse should deflate somewhat the worry over the domino effect if we decide to analyze legal policies affecting home labor using economic understandings. Law's pragmatic focus on remedies has not had an enormous spillover effect into social understandings in non-legal discourse.

Consider the benefits of economic discourse in law about things that we generally view as non-commodifiable. Accident victims who receive pain and suffering damages are not likely to want to have those remedies taken away on the grounds that the hedonic experience of pain is non-fungible or priceless. Pretending that there is a market value to pain, although there is no true market in pain, is a necessary part of improving the welfare of accident victims. This is a partial answer to the question of whether we can know both the price of something and that it is priceless. As lawyers we already do. Incommensurability does not disappear; it simply does not paralyze.

The case of legal remedies is one illustration of a central argument of this article. It is not enough to say that economic rhetoric has an impact on the imagination and to give examples of where that impact is negative. Conceding that rhetoric has an impact is not to concede that in all contexts that impact is negative. It is a conservative leap, grounded in preserving current understandings, to assume that it must be so. We see the creative potential of economics as applied to well-known conventional legal remedies in the tort context. The point is made more salient below when we look at the context of home labor in particular.

\section{The Need for Economic Understandings of Home Labor in Particular}

Consider critics who argue that love and affections are a descriptively accurate way of understanding and explaining productivity in the home. If plural meaning is possible, the emotional account of home labor does not disappear in the face of the economic account. It seems obvious that most labor, including most wage labor, can be multifaceted. It is usually done in furtherance of some

86. See Cass R. Sunstein, Incommensurability and Valuation in Law, 92 MICH. L. REV. 779, 815-816 (1994). 
family commitment, and is often substantively rewarding at a personal level as well.

Having relieved ourselves of the burden of having a singular conception of home labor, we can move on to aspects of home labor that justify the need for economics as one of the plural understandings associated with that labor.

\section{Comparison Between Commodification Concerns Over Wage Labor Versus Home Labor}

\section{a. Similarities Between Waged and Unwaged Labor}

What do waged and unwaged labor have in common? Both improve the welfare of an individual or a family, and neither is leisure ${ }^{87}$ Goods that are made in the home and services that are provided by those who work in the home produce value that improves the standard of living for all in the home in the same way that a wage buys goods and services that improve the standard of living in a home. A meal is prepared and clothes are cleaned because both contribute to individual or collective welfare. Either can be performed at home or purchased as a service with wages earned in the market. Purchase or selfperformance will lead to a similar result: an improvement in welfare.

A person is engaged in leisure activity or simply consuming if the only benefit of her activity goes to her but no benefit would go to her if a third party engaged in that activity for her. Thus, preparing a meal is not leisure because it produces a meal that a worker might still enjoy if it were prepared for her. This is different from true leisure, such as watching a movie, which can only be enjoyed if you do it for yourself. Some people may enjoy meal preparation. Much labor, paid and unpaid, has a leisure component in addition to a labor component, but there is nothing unique about unpaid labor in this respect. ${ }^{88}$

There is substantial sociological literature documenting the way in which women's work is divided between paid and unpaid labor. ${ }^{89}$ Women spend substantially more than half of their working hours doing unpaid labor, while men spend less than a quarter of their working hours on unpaid labor. Women enjoy fewer leisure hours than do men. ${ }^{90}$ Allocating time to unpaid labor is a choice that women make in considering how to improve the circumstances of their families as well as their own circumstances. The social organization whereby more of women's work is performed in the home than men's may result from historic or current gender discrimination in law and culture, from women's socially or biologically determined greater commitment to children, or from other unexplored causes.

87. See Silbaugh, supra note 2, at 10-13; see also Nancy C. Staudt, Taxing Housework, GEO. L.J. 1571, 1620-22 (1996) (discussing the literature dividing labor from leisure).

88. See id. at 10-13.

89. See id. (describing sociological literature on division of women's labor).

90. See id. 
Nonetheless, the fact that women perform more home labor should not reduce the value of that work. Second wave feminism from the 1960s to the present and the antidiscrimination laws of the same time period have brought substantial changes in women's paid labor force participation, with a particular increase among middle class women who had previously spent less time in the paid labor market than lower income women. Yet this radical change in paid labor force participation has not brought a similar change in the distribution of home labor. The time men spend in home labor, reported as a fraction of the time women spend, has changed only slightly, and that change is accounted for by a slight drop in the amount of women's home labor, not an increase in men's absolute hours. ${ }^{91}$ Home labor as an area of significant concern to women's working lives does not appear to be temporary. Therefore, as I will argue below, it is critical to push for the equality of treatment of that work with paid work, and not just to seek the equality of treatment of both men and women in the paid labor force.

\section{b. The Case for Equality of Treatment Between Men's and Women's Work}

The significance of home labor in women's working lives endures, just as the significance of wage labor in men's lives endures. The increasing significance of wage labor in women's lives does not change this reality. Thus if we wish to be vigilant in pursuit of gender equality, we should be vigilant in asking that unwaged labor be subject to the same benefits and burdens as waged labor. If we are willing to live with partially commodified wage labor or if we see a benefit to it, we must have partially commodified home labor. This call for equal treatment between waged and unwaged labor with respect to commodification concerns is supported by several observations. The first observation is that wage labor is not entirely commodified. The second is that home labor is already partially commodified. The third is that affections motivate workers in the wage labor market as they do in the home, both because wage laborers take work relationships seriously and because wage laborers work on behalf of and for the benefit of those with whom they have intimate relations.

Wage labor is not entirely commodified. While we might expect some law and economists to use wage labor as an example of reasonably complete commodification, Radin would contest that description. According to Radin, we as a culture are conflicted between those aspects of wage labor that we recognize as both fungible and as removed from personhood and those that we consider integral to personhood. As a result, we do not have an actual free market in wage labor, but instead regulate heavily in areas ranging from occupational safety to collective bargaining to racial discrimination. Those regulations reflect a societal

91. See VICTOR R. FUCHS, WOMEN's QUEST FOR ECONOMIC EQUALITY 78 (1988); Silbaugh, supra note 2 , at 8-9. 
understanding of employment as having plural meaning; both marketable and non-marketable attributes co-existing. No doubt, there is no societal consensus on where the line of regulation should be drawn, but it is easy to see that plural meanings have been and continue to be accommodated in the paid labor field.

Radin discusses wage labor in this respect, drawing on Hannah Arendt's terminology of "work" versus "labor," but using the terms differently." To Radin, work is partially commodified but has a non-commodified aspect, while labor is entirely commodified-_"Laborers are sellers: fully motivated by money, exhausting the value of their activity in the measure of its exchange value." ${ }^{.93}$ Fortunately, Radin thinks most people are workers. For workers, "there is an irreducibly non-market or non-monetized aspect of human interaction going on between seller and recipient, even though a sale is taking place at the same time." ${ }^{.94}$ Unlike laborers, money does not fully motivate workers, and the value of their activity cannot be fully understood by its price. ${ }^{95}$

While Radin does not discuss a scale by which one is a worker at one end and a laborer at the other, she does discuss artists first and shoe salespeople later. The difference between these, however, might matter to the culture at large when deciding whether to worry about commodification. By this taxonomy, family labor is toward the artist end of the spectrum; its non-market or personal attributes dominate in the popular understanding. However, we might want to object to the categorical assumptions made along this spectrum. Probably some artists, and some family members, are almost entirely mercenary, and probably some salespeople are "artists." Our policy understandings will be shallow if we fail not only to see non-market aspects at work when they are obvious, as in the case of the artist or the family laborer, but also when they are not obvious, as in the case of the shoe salesperson. Radin wants to encourage us to foster the nonmarket aspects of all activities.

While I agree with Radin on this goal, I think the inverse goal is also important: to see the economic aspect of activities that do not appear to be economically motivated. If plurality of understanding is the goal, not just noncommodification, this is justified. For this reason, I encourage some attention to the economics of home labor when making policy decisions, without forfeiting what is uniquely personal about it.

What works for paid labor ought to work for domestic labor. The claim I wish to make is that domestic labor embodies attributes of personhood that we may think imprudent to commodify in a real market; but, at the same time, we can understand domestic labor as susceptible to economic reasoning. The comparison to wage labor is apt not only in bringing unwaged labor closer to the wage labor standard, but also in understanding that the wage labor standard

92. See RADIN, supra note 6 , at 105 .

93. Id.

94. Id. at 107 .

95. See Id. at 105 
contains seeds of the rejection of commodification that many feel should attach to home labor.

Just as important to the call for equality between wage and home labor is the observation that domestic labor is already commodified. There is already a market (or could reasonably be a market) for almost every task that falls within my description of home labor. ${ }^{96}$ There are clear concrete problems for paid domestic workers that arise from a cultural desire to deny that this is so, as I discuss below. There is also an interesting desire to distinguish paid domestic work from unpaid domestic work, to distinguish what Dorothy Roberts calls the menial from the spiritual. ${ }^{97}$ Consider the analysis of the childcare that people provide to their own children by commodification critic James Boyd White: "Such work cannot be segmented into functions and then made the material of the market process, actual or hypothetical, for what the child requires is the sustained presence of, and interaction with, a loving and respectful person, something no alternative can supply." 98 This distinction does not square with many people's experiences. Race, class, and immigration status come to the forefront when considering why the line between spiritual and menial labor is drawn around paid domestic work; Roberts makes the case that this line is racialized. ${ }^{99}$ In addition, the important gender roles of the middle class household, where there is no paid domestic labor, may be supported by a denial of the reality of an existing market in home labor. Denying the reality of an existing market assists in maintaining the image of the unpaid household laborer as a non-worker, and creates an illusion of her work as simply an expression of affections demonstrated through her activities.

A final potential substantive difference between waged and unwaged labor, that could be the implicit ground on which to treat them differently, may be the relationships surrounding home labor: the emotional relationship between the worker and the beneficiaries. However, we can not universalize wage labor as functioning without those relationships. Work in a family business can be waged as can work in a small business, work in a sole proprietor business, or work in the home as paid domestic labor. Even work in a large business includes important localized relationships among workers. Moreover, most people in the wage labor market probably consider family members to be beneficiaries of their work through wages returned to the family. Indeed, Arlie Hochschild, who popularized the concern over women's double work day in her 1989 book, The Second Shift, ${ }^{100}$ has turned her focus to the study of the relational significance of

96. That there is or at least could be a market is important to the definitional line between labor and leisure. See Silbaugh, supra note 2, at 10-11.

97. See Dorothy E. Roberts, Spiritual and Menial Housework, 9 YALE J.L. \& FEMINISM 51 (1997).

98. White, supra note 1 , at 190.

99. See Dorothy E. Roberts, Spiritual and Menial Housework, 9 YALE J.L. \& FEMINISM 51 (1997).

100. See Arlie Russell Hochschild, Work: The Great Escape, N.Y. TIMES, Apr. 20, 1997, \$6 (Magazine), at 50. 
wage labor. She concludes that individuals today seek and find many of the emotional benefits of family life in the workplace now that the home carries the burden that was once associated with the rushed workday.

The claim for equality in how we treat work, both men's and women's, proceeds on several fronts. It can not be especially harmful to commodify women's work; instead, it carries the same risks, not qualitatively worse ones, as other types of work. In saying this, we must be mindful of several things. First, wage labor is not fully commodified, and domestic labor is already partially commodified. Second, it may be argued that the relationships between workers and beneficiaries is substantively different for paid and unpaid workers. But we may decide that that is a line too starkly drawn. Not only do most workers in the paid labor market consider family members to be the beneficiaries of their work, but much paid work also involves family-like relationships, sometimes literally, as in a family business, and sometimes metaphorically.

Finally, we should question why the substantive line between commodifiable and non-commodifiable labor is also a substantive gender line. This point is discussed below, where I note that many of the areas where commodification concerns arise touch on women's labor. Given that fact, we will need to question what notions of femininity govern in those situations.

\section{Women as Non-commodifiable: Questioning the Origins of an Idea}

Does concern about the comparison between wage labor and home labor commodification grow out of an implicit assumption that there is something intrinsically different about home labor? We might want to ask whether it is coincidental, or instead highly relevant, that that intrinsic difference at play in analysis also cuts along gender lines: women's work, hereby, would be essentially non-marketable. Consider the problems with assuming that women are inclined to make gifts of attributes of their personalities. Women serve, men sell. It is a familiar notion about which many feminists have been skeptical. ${ }^{101}$

\section{a. The Gender Line: Cashless Women}

At a practical level, women should at least be wary of anti-commodification arguments, because these arguments arise when women receive money for something, not when women are paying money for something. The argument is used most frequently in legal discourse when talking about women receiving money for surrogate parenting and sexual contact, and herein for household labor. While Radin extends the argument into gender neutral territories, such as

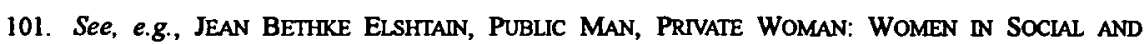
Polmical THOUGHT (1987); Frances E. Olsen, The Family and the Market: A Study of Ideology and Legal Reform, 96 HARV. L. REV. 1497 (1983). 
housing, most of the commodification red flags are raised by her and by others when discussing women's commodification.

One might respond that the emphasis of the anticommodification argument is that some aspect of women's personhood is going to be sold, not that women are about to receive money. It is the sale that is objectionable, not that women may end up with cash. Consider, though, that it is not uncommon to find people who approve of altruistic transfer in these same areas, for example, human egg donation and surrogacy. In fact, the current fee caps in both of these fields reflect that ideal in practice: donors are not supposed to be too motivated by money, so fees are held down to ensure that there is a partially altruistic motivation for donating. ${ }^{102}$ In these cases, it seems arguable that the difference that a woman experiences may simply be whether money comes to her, and how much, as compared to other wage labor that she might similarly perform from partially altruistic motivation. ${ }^{103}$ This difference occurs in the name of noncommodification. It is worth asking whether Anderson's concern about exploitation due to the commodification of women's reproductive capacity might just as easily turn into exploitation from non-commodification, not just in a "nonideal" world. Here the mixed motivations of women are exploited by highlighting the altruistic aspects of those motives in a discriminatory fashion. Only women's mixed motives relating to feminine activities are highlighted and offered as justification for leaving women without cash. Mixed motivations in the labor force at large do not require regulatory practices aimed at keeping wages down.

Social practices also exist where the characterization of the problem as "withholding money from women" seems even more apt at the practical level than "preventing the sale of women," given the particular form that current decommodification takes. Prostitutes and pimps have a relationship that results where prohibition on sale ensures that although a female attribute is being sold, a woman is not getting most of the money. The "transitional balancing" questions raised by commodification and prostitution have been widely debated elsewhere. I raise it to illustrate that protecting women from sale does not necessarily go hand in hand with preventing women from receiving cash. Women can be sold and remain relatively cashless. Few would argue that the current form of the criminalization of prostitution is intended or designed for the protection of prostitutes, and so the lack of connection between non-commodification (and its female cashlessness) and sale is hardly remarkable. But in the reproductive areas of surrogacy and egg donation, non-commodification ideals drive the policy of leaving women relatively cashless despite their (partial?) sale.

102. See Carol Sanger, Separating from Children, 96 CoLUM. L. REv. 375, 451 (1996); Sharon Lerner, The Price of Eggs; Undercover in the Infertility Industry, MS., Mar./Apr. 1996, at 28, $29,34$.

103. Think of a school teacher, for example. This is the lay understanding of altruism, not the economists' understanding of human behavior, which resists the existence of altruism. 
We do not usually see the anticommodification argument raised as forcefully when things typically associated with male personhood are being sold. While it may be that women's personhood is more at risk for being inappropriately objectified and commercialized, we should at least consider an alternative understanding of why commodification concerns focus on women's issues. It may have as much to do with notions of femininity and a desire to elevate a romantic essentialism about femininity as it does with a desire to protect women's integrity. Consider Anderson's argument that women's reproductive labor is inappropriately alienated by surrogacy because a surrogate mother must "divert [her labor] from the end which the social practices of pregnancy rightly promote-an emotional bond with her child."104 It is not clear why the end which Anderson prefers for women's labor must be extinguished by money, but it is clear that her argument leaves women without money for their labor. If a reinscription of the public-private spheres ideology on which market rhetoric thrives occurs around women's home labor, it may depend on a particular notion of femininity that has as one of its characteristics cashless women. Perhaps Anderson recognizes this, but sees it as a necessary trade-off for the preservation of familial bonds. ${ }^{105}$ She does not explain though, why it is a trade-off; why markets and monetary exchange cannot coexist with expressions of affection in a realistic reflection of women's mixed motivations. We have the example of wage labor as an area where monetary exchange and mixed motivations coexist.

This is not to say that the anticommodification argument is insincere. But at least Radin readily admits that gut instinct plays a significant, perhaps deciding role in drawing a line between things essential to personhood that should not be commodified, and things that are less essential to personhood and therefore can be commodified. ${ }^{106}$ These "gut instincts" must be informed by cultural gender understandings.

It certainly seems plausible that what makes us uncomfortable about selling female reproductive capacity, for example, is its subversion of the motherhood role, not just its potential to lead to exploitation. In contrast, consider the rather dull response to the sale of sperm. Attaching anticommodification concerns only to women is a reincarnation of the old public-private split, whereby things feminine are non-market. Domestic labor has such a strong parallel with wage labor in terms of its content and the role it plays in a worker's life that the anticommodification concern raised against only home labor seems a clear case of reinscribing gender roles. ${ }^{107}$

104. ANDERSON, supra note 8, at 82.

105. See ANDERSON, supra note 8, at 182-85

106. See RADIN, CONIESTED COMMODITIES, supra note 6, at 11-12.

107. This point is slightly less visible in the case of surrogacy. The male parallel (sperm donation) is freely marketable, because the female counter-part (pregnancy) is restricted in the market: thus a male-female split on the appropriateness of commodification occurs. However, while the two practices (pregnancy and sperm donation) are very different in substance from one another, other rationales for their different treatment obscure the importance of reinscription of gender roles. 
Certainly there is room for the argument that commodification of things like housing and wage labor harms male personhood. The fact that we are more concerned about commodification of women's personhood does not mean that we have erred with respect to women; we might have erred with respect to men. Radin's work suggests this. But we must at least consider the gender line in the anticommodification discourse and its possible origins in gut instincts, including our own, which we might not want to trust. And in deciding whether we are right to permit partial commodification of "men's" personal attributes, such as wage labor, we need to ask which gut instinct is stronger: the one that permits wage labor, or the one that doesn't permit market analysis of home labor. The partial commodification of wage labor is acceptable to most people in a world of scarce resources that is as thoroughly organized around markets as our own. Much that is personal is created and produced on the market, and home labor is not special in that respect.

This argument reinforces my claim for the equality of treatment between home and wage labor, and further suggests that different treatment on commodification grounds tracks different treatment in other areas, such as reproductive capacities, while falling straight down gender lines.

\section{b. Help from the History of Notions of Domestic Labor}

As argued above, we should care whether surrogacy contracts, for example, might be illegal to preserve the human dignity of child and mother, or because the mother undermines traditional family roles by selling her reproductive capacity. We must also be skeptical of our ability to produce a coherent answer to that question. Similarly, we need to know why we instinctively resist the commodification of home labor. There may be a difference between noncommodified values at a deep level and sentimentalization.

To sort that difference out, we have to scrutinize what women are actually doing in the home, and not put the work women are doing on a pedestal. It is dangerous to pretend that domestic labor is not understood as work because there is something essentially too close to personal human identity in performing this work. The crucial question is whether it is not understood as work because women do it, that is, whether work within the home is doctrinally cast as an expression of affection at least in part because that justifies women's inferior economic status.

One way to explore the difference is through a search of doctrinal origins. Here, Reva Siegel's work is particularly useful. ${ }^{108}$ She claims that sentimentalization of women's home labor happened as a mechanism for

108. See Reva B. Siegel, Home as Work: The First Woman's Rights Claims Concerning Wives' Household Labor, 1850-1880, 103 YaLE L.J. 1073 (1994); Reva B. Siegel, The Modernization of Marital Status Law: Adjudicating Wives' Rights to Eamings, 1860-1930, 82 GEO. L.J. 2168, 2181-96 (1994). See also Amy Dru Stanley, Conjugal Bonds and Wage Labor: Rights of Contract in the Age of Emancipation, 75 J. AM. HIST. 472 (1988). 
maintaining gender stratification in the face of a moment of possible transformation for status relations. If the sentimental notion of home labor in law is arguably born out of instrumentalism working against women, then we want to be careful saying that those sentimental notions are integrally connected to women's human dignity. Siegel has tracked the legal response to the Married Women's Property Acts and the Earnings Statutes of the nineteenth century. Before their enactment, legal understanding of women's home labor had been clearly and openly economic, with men owning their wives' labor and that labor viewed as of primarily monetary value. Both statutory reforms had the potential to completely change the status relationships between husbands and wives and the texts of the statutes suggested they could do so by giving wives economic rights in all their labor, including their labor at home. But Siegel carefully examines the early judicial interpretations of those statutes and concludes that judges limited them so as not to disrupt labor relations within the home. They did so by minimizing the economic significance of home labor that had been openly acknowledged in the past. They instead introduced a sentimentality to home labor that had not previously informed legal discourse, even though it was available in the discourse outside of law at the time. The history of how this work became sentimentalized tells us that it was not women who infused the work with its domestic love aura.

This is not to say that the suspicious origins of the idea that home labor is something other than wealth-generating can decide whether or not we ought to look at home labor that way today. Origins are not decisive. I have, for example, argued that the questionable gender presumptions of Gary Becker and the original proponents of economic understandings of the family should not prevent feminists from employing economic understandings. But if the different understandings of unwaged home labor and wage labor are not intrinsic, if they are historically placed, then we should be asking whether it is particularly helpful or instead harmful at this point in time to be viewing home labor as different from wage labor.

The foregoing should serve as a partial response to Anderson's concern that commodification invites exploitation. It seems just as plausible to argue that pricelessness invites exploitation. Refusing to consider the economics of home labor perpetuates the idea that women are inclined to serve and to gift their work. It would be a strange scenario whereby affections that accompany labor penalize rather than enhance the value of that labor, admitting that value has a material component for women as well as for men.

Even if rhetoric influences relations, the foregoing should leave us wondering why those who are interested in the impact of rhetoric dislike economics so strongly. The belief that rhetoric may reorganize understanding does not demonstrate that there is no role for economics if reorganization is in order. To the contrary, if there is power in the observation that analysis can remake relations, economic analysis may be an important creative force in this 
particular context where current relations are not ideal. This single context, where gender relations might benefit from the reimagining that economics might provide, throws a wrench into the general claim that economics should be "vigorously resist[ed]"109 because language may be constitutive. That claim must instead recognize context.

\section{APPLICATIONS OF THE ARGUMENT}

The anticommodification literature routinely treats commodification, or partial commodification, as a necessary evil where it applies. Radin has identified this as the double-bind: wanting a perfect world of noncommodification, but accepting that commodification may be necessary in an imperfect world. I think the case for economic or market reasoning can be made more affirmatively than that.

Consider White's argument that the way we speak has a constitutive effect on what we speak about. ${ }^{110}$ To White, this is a strong argument against economic rhetoric. ${ }^{111}$ But it is not evident why this must follow from his analysis. Even if economic rhetoric remakes relations, that may be a positive development in some areas, with domestic labor being a prime example. White's analysis purports to critique economic rhetoric as an abstract idea to be "vigorously resist[ed]." ${ }^{112}$ There is something quite conservative about this conclusion: it depends on the idea that there is something very valuable to preserve in current discourse. That discourse does not float in the air, but it has a particular context, and we need to look at that context to know whether remaking understandings would be a positive or negative development.

I think it is important to consider the costs of sentimentality. What harms are created by an ideal of non-commodification? One answer might be in the gender equality argument made above. A second might lie in concrete doctrine: economics is not a necessary evil but an additional tool of analysis that permits us to see one more facet of a phenomenon. That new angle opens up additional creative opportunities for problem-solving. My task in this Article is not only to make a space for economic understandings in the abstract. I am interested in the benefits of an economic perspective on domestic labor. In that light, consideration should be given to what economics can add to the following concrete doctrinal problems associated with home labor.

109. White, supra note 1 , at 166.

110. See id. at $161,164$.

111. See id. at 170-74.

112. Id. at $161,164$. 


\section{A Welfare}

Nowhere is the need for an economic perspective on women's domestic labor more pressing than in the welfare discourse. Mothers who receive Aid to Families with Dependent Children (AFDC) are almost by definition caregivers to those children. Children in poverty who are eligible for aid need not only marketable goods, such as food, shelter and clothing; but they also need supervision, education, household management including food preparation and laundry, and caregiving to ensure a measure of personal welfare. Typically, they receive the latter from a parent, usually a mother or another woman who plays a mothering role.

It is not a difficult task for an economist to attach economic value to this contribution by an AFDC parent. ${ }^{113}$ The New Home Economists have brought an analysis to divorce law that gives an account of women's caregiving and home management as contributing to family wealth and welfare in a manner that is economically equivalent to wage labor. Although these economists have focused their energies on divorce law which applies primarily to the middle and upper classes, the work performed by caregivers is in many ways similar across class lines. To the late twentieth century economist, there is moral equivalence between paid and unpaid work in terms of productivity. The economist also brings an understanding of what will be lost in terms of non-monetary income, and material welfare, if an unpaid worker must reallocate her time to paid labor.

In contrast, the all-too-familiar complaint that the welfare system itself is responsible for poverty is built on an understanding that home labor is not, in fact, work. In the words of former presidential candidate Robert Dole:

[R]eal welfare reform must include a real work requirement, which in no uncertain terms requires able-bodied welfare recipients to find a job, not stay at home, and not stay in a training program forever, but to go to work in a job, hopefully in a real job in the private sector. When it comes to escaping poverty, we know that the old American work ethic was true, because work works. ${ }^{114}$

Dole's comments reflect the common refrain in the public discourse on welfare: welfare recipients by definition do not work; a work ethic must be cultivated among welfare recipients, and real work is at a job in the private sector, not staying at home. If we bring an economic understanding to home labor, Dole's comments seem fraught with troubling analysis. Moreover, potential solutions to

113. In fact, when all the rhetoric at the most public level shakes away, many in the hands-on public policy arena can comprehend the difficulties associated with a work requirement for mothers of very small children, which explains how assistance with childcare manages to appear in the debates at all.

114. Excerpts From Dole and Clinton Speeches on Redoing Welfare, N.Y. TIMES, Aug. 1, 1995, at A10. 
the welfare "problem" would be much better crafted were the productivity of childrearing a factor in the analysis.

For those who think that the role of caretaking in the home is significant, this common spin on welfare is problematic. But one might respond with a case for public support of childrearing that does not use economic rhetoric. We might instead argue that mothering is a competing value with work, equally deserving of society's active support. We would not be arguing that childrearing, or mothering, as Martha Fineman calls it, ${ }^{115}$ is itself work, but only that Dole is wrong in placing work above all else. What is gained by arguing that home labor is economically and morally equivalent to wage labor?

The answer is partially strategic. If the moral claim for societal support of wage labor proceeds on the theory that wage labor can be judged by a certain set of criteria, if unpaid domestic labor measures up to wage labor on these same terms, then society should support home labor. If this were a purely instrumental point, it might seem an inappropriate argument at the academic level, being appropriate instead only for a strategy room. But more might be said for this approach, if Dole's basic instinct that work is valuable has any merit.

Sociologist William Julius Wilson has argued that work is the organizing structure of the human biography. ${ }^{116}$ In this regard, he sounds like many neoconservative academics and commentators who fault a "culture of poverty," meaning a culture where work is not valued, for the economic plight of the very poor in American urban areas. But unlike these neoconservatives, Wilson argues that joblessness is a result of economic structure, which creates social isolation among those who cannot find work. ${ }^{117}$ Wilson is friendlier than most liberals to the notion that there may be a distorted work ethic among the "truly disadvantaged," but he views that ethic as the result of joblessness, not the cause of joblessness. Unfortunately, Wilson does not go the extra step in asking whether uncompensated labor in the home demonstrates a healthy work ethic. Instead, he favors policies that promote paid employment on an equal basis for all Americans. ${ }^{118}$ Wilson taps into an understanding of the importance of work on which there is a broad societal consensus. Wilson may be right that work is deeply understood as an organizing structure of human biography, and he may be very much in need of a better economic understanding of unpaid home labor in order to bring it within his definition of work. ${ }^{119}$

Consider the argument put forward by Mark Kelman. ${ }^{120}$ Kelman defends the decision not to tax imputed income because it preserves individual liberty to

115. See Martha Albertson Fineman, The Neutered Mother, the Sexual famity, and Other TWENTIETH CENTURY TRAGEDIES 233-35(1995).

116. See WILLIAM JULIUS WISON, WHEN WORK DISAPPEARS 73-75(1996).

117. See William JuluUs Wison, The Truly Disadvantaged 55-62, 137-39 (1987).

118. See id. at 109-24.

119. See id:; WLSON, supra note 116, at 73-75.

120. Mark G. Kelman, Personal Deductions Revisited: Why They Fit Poorly in an "Ideal" Income Tax and Why They Fit Worse in a Far from Ideal World, 31 STAN. L. REv. 831, 880 (1979). I am indebted to Nancy Staudt for drawing me to this example. 
conduct private activities outside the market. His line is market and non-market, rather than productive versus unproductive. Kelman makes no distinction here between underutilizing skills by, for example, training as a physician but spending your days on the beach and working without pay in the home. This is an insult to the unpaid home laborer and highlights the difficulty with deemphasizing the economic nature of home labor. Should the value of home labor rise and fall with the value of sunbathing? Even most people who are truly sympathetic with welfare recipients would agree with Wilson in putting work above leisure as a personal good. Consequently, it is particularly important to appreciate the economic aspects of the activities of an AFDC mother who is taking care of her children.

Economic rhetoric in this context has an important dignitary component. It recovers women's work from the misunderstanding that it is unproductive, and that the ethic it reflects is similar to that of the sunbather. It also has an important pragmatic, policy component. The need for substitute care, not as an afterthought, but as a core economic difficulty with workfare programs, needs to be better understood in the mainstream debate on welfare. ${ }^{121}$

\section{B. Paid Domestic Workers}

Paid domestic labor is still almost exclusively done by women, but as a profession is not representative of women across racial and socio-economic lines. Instead, paid domestic laborers are historically and presently overwhelmingly women of color, immigrants, or both. According to the Bureau of Labor Statistics, 691,000 people are "private household workers" in the U.S., meaning that they perform either childcare or cleaning in a private home for pay. ${ }^{122}$ There are another 555,400 recorded as doing home health care for pay, and 501,900 providing child day care outside of the home for pay. ${ }^{123}$ These three categories alone represent $1,748,300$ workers of record. Almost all are women: $96.3 \%$ of the 691,000 private household workers. ${ }^{124}$ The majority of those who perform housecleaning are Black or Hispanic (fifty-one percent). A substantially disproportionate number of private household workers overall are Black or

121. One might argue that the very existence of welfare represents a recognition of the value of childrearing. But benefits under the Social Security Act are tailored to the kinds of familial relationships that have been historically in place in a given family, not to the work done. In other words, a widow receives more under the SSA for her work than a never-married, despite the similarity of their work. This weakens considerably any claim that payment is for work; rather, as I argued in Turning Labor into Love, supra note 2, at 38-41, 67-72, payment is for relationships, for love.

122. BuREAU of LABOR STATISTICS, U.S. DEPARTMENT OF LABOR, EMPLOMMENT AND EARNINGS A-25 (Feb. 1996).

123. BUREAU OF LABOR STATTSTICS, U.S. DEPARTMENT OF LABOR, EMPLOYMENT, HOURS AND EARNINGS, U. S. 1990-1995 (Sept. 1995).

124. BuREau of Labor Statistics, U.S. Department of Labor, EMploment and Earning, MONTHLY, JANUARY 1994, TЫ. No. 649 (Jan. 1994). 
Hispanic (nearly forty-four percent). ${ }^{125}$ These statistics do not include launderers, drivers, secretaries, gardeners, dog walkers, grocery delivery workers, or the numerous other job classifications that encompass the work of the unpaid household worker. ${ }^{126}$

Thus, discussions of whether home labor should be commodified proceed from the outset on a premise that insults the population of women who already perform domestic labor for pay. Quite simply, the market already exists. Paid domestic workers bear an extremely unfair burden generated by the precise mode of analysis I criticize: the desire to construe home labor as something other than work. The problem of the pricelessness of unpaid home labor bears down on the paid domestic laborer, both in broad social understandings and concretely through impaiment of the ability to achieve a remotely even playing field on which to sell her labor. The former point can be illustrated through an examination of a few of the labor laws that apply to paid domestic workers. The latter point can be illustrated through a look at the tax treatment of unpaid labor.

Domestic workers are explicitly exempted from coverage under the National Labor Relations Act, ${ }^{127}$ the Occupational Safety and Health Act (OSHA) $)^{128}$ and almost all Workers' Compensation statutes. ${ }^{129}$ These exemptions are not on grounds related to the size of the employer or the number of employees. ${ }^{130}$ From the NLRA, there is no available legislative history explaining the exemption. But there is a suggestion from early state labor law that the exemption is directly related to the idea that the home is about emotions, not industry. A 1939 case refused to give a domestic worker the right to picket his worksite under state labor law because the home is "the abiding place of affections, esp[ecially] domestic affections." ${ }^{\prime 31}$ This notion of affections, so prevalent in describing the home labor of the unpaid houseworker, stripped the paid domestic worker of her basic employment rights under labor laws. The OSHA exemption applies only to "ordinary domestic household tasks" such as cooking, childcare and cleaning. ${ }^{132}$ From OSHA the exemption is said to be "on public policy grounds," which go entirely unstated. ${ }^{133}$ If this is to mean that the grounds are supposed to be

125. Id. The terms "Black" and "Hispanic" are those used by the Census Bureau in gathering the foregoing data, and thus the survey participants are self-identified as such at least for the purposes of answering the survey.

126. I could only obtain racial classifications for the private household worker data, not for the home health care or public day care data, thus the incomplete reporting of race data here.

127. 29 U.S.C.S. $\$ 152(3)$ (Law Co-op. 1996).

128. 29 C.F.R. $\$ 1975.6$ (1995).

129. 4 ARTHUR LARSON, THE LAW OF WORKER'S COMPENSATTON app. A-5-1 (1995); Silbaugh, supra note 2 , at 78 .

130. The exception is that some workers' compensation laws apply to domestic workers when two or more are employed full-time at the same site. Those states, however, do not have that limitation on other employees who work as sole employees outside the home. For a thorough discussion of the doctrine discussed here, see Silbaugh, supra note 2, at 72-79.

131. State v. Cooper, 285 N.W. 903, 905 (Minn. 1939) (quoting WEBSTER's NEW INIERNATIONAL DICTIONARY (2d ed. 1935)).

132. 29 C.F.R $\S 1975.6(1995)$.

133. Id. 
obvious, we can only again wonder why it should be obvious that paid domestic workers are different from all other paid workers to whom society feels it should guarantee a safe work environment. The attempt to remove paid domestic workers from the formal economy is one serious consequence of the general desire to view household labor of either sort as being without economic consequence.

Economic understanding can help us even more concretely to understand some of the reasons, in addition to those of race and class stratification, why paid domestic labor is so poorly compensated. There is a reasonable argument, which I will set out below, that unpaid domestic labor receives a tax subsidy, while paid domestic labor does not. Therefore, the price that can be charged for paid domestic labor must be lower than it otherwise could be in order to compete with the tax-subsidy given to unpaid domestic labor. Once explained, this point underscores the benefits of economic analysis applied to domestic labor, in this case revealing a market distortion that works against paid domestic workers.

Housework performed in the home by a family member is not "taxable income" for the purposes of the federal income tax, despite the general rule that non-monetary income and income from informal economies is taxable. ${ }^{134}$ The exception is for income that does not come from a market bargain, whether it is monetary or not. This is thought to exclude household labor, which is prejudged as unbargained-for. ${ }^{135}$ Economists and many tax scholars have recognized the difficult distortions that the failure to tax imputed income introduces into the family economy both in terms of decision-making as to paid labor force participation versus home labor and in terms of distributional issues surrounding government benefits. ${ }^{136}$ The failure to tax imputed income from unpaid household labor works as a tax subsidy to the choice of unwaged over wage labor, and a tax subsidy to unpaid home labor in particular. As a result, a person deciding whether to allocate time to paid or to unpaid labor may take account of the extent to which wages from paid labor will be reduced by taxes, while value produced by home labor will be enjoyed in full. It seems plausible that there are cases where this calculation does occur, as women figure out the high cost of returning to the paid labor force after the birth of a child and consider the cost of purchasing childcare out of after-tax wages when they could provide that childcare themselves without taxation. Recent scholarship on this topic relies on an understanding of the economic productivity of home labor, and is an example of the insights that can come from an economic understanding.

So far analysis within the tax context has only examined the impact of tax subsidies on the unpaid houseworker. However, the failure to tax unpaid

134. See Staudt, supra note 5, at 1575-76.

135. See Silbaugh, supra note 2 , at $52-54$.

136. For the decision-making component, see Edward J. McCaffery, Taxation and the Family: A Fresh Look at Behavioral Gender Biases in the Code, 40 UCLA L. REV. 983 (1993); and Richard A. Posner, Conservative Feminism, 1989 U. CHI. LEGAL F. 191. For the issue of the distribution of government benefits, see Staudt, supra note 5. 
housework also impacts the paid domestic worker. Since the majority of home labor is unpaid, the paid domestic worker competes for a wage against a taxsubsidized unpaid worker. This may be one of the factors that drives down the wages of paid domestic workers. ${ }^{137}$ This hypothesis should be explored by economists, and if it appears valid, should be an important public policy issue for law reform. This issue could not be understood without an understanding of the economic productivity of home labor and of the wealth created by it.

The paid domestic worker is the victim by association with the unpaid domestic worker, both by suggestion and directly. First, the paid worker is denied the benefits of labor law, in some cases explicitly on the grounds that the home is the site of affections, or that housework, as distinct from other work in the home, raises unique but unspecified public policy concerns. Like the unpaid worker, the paid domestic worker's job is something different from all other work, whether performed in a house, as a sole employee, or part-time. The waged and unwaged domestic workers are conflated. When one fails to see the unpaid domestic laborer in economic terms, it becomes more difficult to see the paid domestic laborer in economic terms. This might help to explain the absence of labor law protections to paid domestic workers. The families who employ domestic workers join in this perspective; the household that is safe enough for their domestic life must be beyond government safety regulations for their employees. Second, in addition to that suggestive function, the failure to understand unpaid labor in economic terms has a more direct impact. By not taxing unpaid home labor, the competitive price of paid home labor is reduced. This reduction may assist in perpetuating poverty among paid domestic workers. Conversely, at those times when a price might be placed on unpaid home labor in law, as in the wrongful death suit or the divorce context, that price has been deflated by distortions in the market for paid domestic labor.

\section{Social Security}

The system of compensating unpaid home laborers through spousal and survivor's benefits reveals a legal and cultural reliance on the family economy to provide old-age security to home laborers. Home laborers receive social security only if they are married or were once married for at least ten years to the same person, and cannot combine that benefit with credits in the social security system accrued on their own accounts in the paid labor market if they have spent some time working in each place. ${ }^{138}$ This makes home laborers vulnerable to the vicissitudes of family structure, thereby both limiting their choices as to family structure and placing the burden of an unchosen unconventional family structure

137. See Silbaugh, supra note 2, at 79-83

138. See FINEMAN, supra note 115 (pointing out legal and cultural reliance on family to handle dependencies in many contexts, and using welfare/SSI as one example); Mary E. Becker, Obscuring the Struggle: Sex Discrimination, Social Security, and Stone, Seidman, Sunstein \& Tushnets Constitutional Low, 89 ColuM. L. REV. 264 passim (1989); Silbaugh, supra note 2, at 38-41. 
on the shoulders of home laborers. For the paid worker, these family structure issues are irrelevant to entitlement under the system.

A social security system that provides for unpaid domestic workers on their own account would be far superior to the system we currently have. One option would be a guaranteed income support to all citizens. This system, however, would be a huge departure from our current work-based system, since it would need to include both the sunbather and the childrearer on equal footing. Less of a departure is possible. An economic understanding of the productivity of home labor could permit home laborers to stand on their own in the social security system just as wage laborers do. Contributions could be made to the social security system for being materially productive. These contributions could be made on either a voluntary basis or on a mandatory basis as the participation of wage laborers is mandatory. ${ }^{139}$ But contributions from unpaid laborers cannot be assessed without some method of calculation. Economic valuation on which to base contributions in the absence of a real market is complicated but possible, ${ }^{140}$ but not if we foreclose economic understandings of home labor on commodification grounds.

\section{Contracts}

The area of contract law that most directly implicates home labor is the law of premarital or marital agreements. ${ }^{141}$ This peculiar set of rules reveals a rejection of an economic understanding of home labor in favor of a highly sentimental one. Although this has not always been the case, when spouses today sign an agreement with regard to the disposition of either property or income in the event of death or divorce, courts will generally enforce it. ${ }^{142}$ In this respect, courts recognize a right of contract between spouses over what are overtly financial matters. This right is used primarily to protect financial assets and income owned and earned by one spouse from the other.

However, when spouses sign an agreement whereby one will pay the other for home labor, courts will not enforce it. ${ }^{143}$ This refusal rests in part on some historical peculiarities of family law: husbands traditionally owned their wives' labor, and so it would not make sense for them to pay for it. This history surfaces in cases today, where courts find that the houseworker has offered no

139. There are pros and cons to making a social security system for unpaid workers voluntary versus mandatory. While the mandatory system would ensure full coverage, many families would have cashflow difficulties making payments when there is no cash income from which to deduct them.

140. See Silbaugh, supra note 2, at 79-81 (discussing the various methods used by economists to estimate the value of unpaid labor, as well as their strengths and weaknesses).

141. For an extensive discussion of the doctrinal issues raised here, see Silbaugh supra note 2, at 28-36.

142. There are qualifications here. In some states, courts will examine the agreement for substantive overreaching under a standard that appears to be more substantive than the traditional unconscionability doctrine in ordinary contract law. Not all courts do this, however. Some states are also more inclined to enforce an agreement touching on the disposition of property than on the disposition of income, while most states draw no distinction between the two. Id. at 31 .

143. See Silbaugh, supra note 2, at 32-38 \& n.115. 
consideration for the contract because she is only doing what she is legally obligated to do. ${ }^{144}$ This reasoning is supplemented by an updated rationale: home labor is not about money, or ought not to be about money, but is instead about marital love and affections. ${ }^{145}$ These courts reason that despite the parties' agreement to monetize the home labor, it is of a personal nature that removes it from the sphere of ordinary premarital agreements. It should be noted that courts do not raise difficulties with enforcement or monitoring of such agreements as a reason to treat them differently from premarital agreements goveming property and wages. ${ }^{146}$

The result of courts' treatment of home labor is a striking inequality in the treatment of waged versus unwaged labor, or traditionally male versus traditionally female labor. The fact that wage labor is "financial" hardly makes it irrelevant to familial care and emotions. Most people work for wages in order to spend those wages caring for family. In this respect, we are permitting agreements now that are deeply personal simply because we perceive them as of an economic nature.

Once again, the question arises: are enforceable housework agreements a utopian vision? The preceding analysis cannot answer that question, being one of the substance of legal marriage. However, my analysis insists that the answer be the same for unwaged labor as it is for waged labor. To create equality between waged and unwaged labor, one must have an economic understanding of home labor. Economics advances our understanding of the multifaceted nature of activities within the home.

That which can be monetized can be owned in premarital agreements, and protected from a spouse in premarital agreements. That which is not monetized cannot be bargained for legally, carries no personal entitlement, and receives no protection. This problem of monetizable interests receiving protection while nonmonetizable interests do not implicates many women's interests in marriage, such as caretaking, homemaking, and child custody. An economic understanding of home labor is once again critical to achieving equality of treatment between men's work and women's work. Whatever commodification risks attend to enforcing housework agreements attend equally to enforcing agreements that keep wages and property inaccessible to a spouse. The broader question, whether any of these agreements ought to be enforceable, can be better answered once the economic equality between waged and unwaged labor is understood.

144. Of course that duty is now stated in gender neutral terms.

145. See, e.g. Borelli v. Brusseau, 16 Cal. Rptr. 2d 16 (Cal. Ct. App. 1993); State v. Bachmann, 521 N.W.2d 886, 888 (Minn. Ct. App. 1994); Hughes v. Lord, 602 P.2d 1030, 1031 (N.M. 1979); Kuder v. Schroeder, 430 S.E.2d 271, 272-73 (N.C. Ct. App. 1993).

146. I am aware of no housework for wages case where this concem is raised, even tangentially, as a reason to be concerned about enforcement. 


\section{E. Divorce}

Divorce law presents more opportunities to use economic understandings of home labor, and in this area legal academics have done so with increasing frequency. ${ }^{147}$ However, more opportunities remain. For example, the division of property upon divorce shows what an economic understanding can bring that is currently missing to a discussion of family law policy. While most families have no substantial assets to divide at divorce and instead live off of earned income, the property example illustrates the tendency of judges to ignore the economic understanding of home labor. Before the divorce reform of the last 30 years, divorce meant that property, when there was any to distribute, remained with its owner of record, usually the male wage earner. ${ }^{148}$ Following the divorce-law reforms in many states, courts have begun to consider the source of wealth as relevant to distribution upon divorce, in addition to record of ownership. This change is beneficial to women because these reformed statutes require courts to consider not only the contributions of a wage-earner to the accumulation of wealth, but also the contributions of a homemaker. This development shows a subtle understanding of the role of home labor in wealth creation. When the family owns property, not only the wage-earner, but the home laborer as well, has worked to accumulate that property, whether directly by increasing the value of the asset through unpaid labor as through home improvements, or indirectly by providing day-to-day family subsistence that freed up cash for the purchase of assets. The statutes have increasingly been interpreted to mean that full-time homemakers, under this specific provision, can receive a substantial portion of family wealth even if it was purchased with cash held in the name of a full-time wage-earning spouse. In some states, this has become a presumption of a 50-50 split of assets.

One might guess from this emerging jurisprudence that courts are comprehending the economic significance of home labor. But there are hints that this is not the case. It appears that courts are instead reinterpreting marital obligations as requiring wealth sharing without regard to contribution. ${ }^{149}$ If this is the case, I do not argue that this is normatively undesirable. To the contrary, it may reflect some aspects of a better substantive marriage law to de-emphasize contribution altogether. ${ }^{150}$ But under current law, where contribution to wealth

147. See, e.g., MARTHA Albertson Fineman, THE Illusion of EQuality: THE RHEToric and

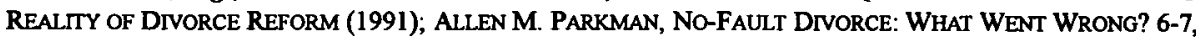
130-37 (1992); Elisabeth M. Landes, Economics of Alimony, 7 J. LEGAL STUD. 35 (1978); Posner, supra note 28; Cynthia Stames, Divorce and the Displaced Homemaker: A Discourse on Playing with Dolls, Partnership Buyouts and Dissociation under No-Fault, 60 U. CHI. L. REV. 67 (1993).

148. The road to divorce reform included a significant softening of this rule through equitable remedies such as constructive trusts, but these were unreliable.

149. See Silbaugh, supra note 2, at 56.

150. One can certainly imagine a better law still, where dependent children, rather than adult affiliations, were the significant basis for obligation. See generally FINEMAN, supra note 115 . But I take that to be much further outside the mainstream vision for legal structuring of the family than is a vision of substantive obligations without regard to contributions. 
does matter, I argue that present interpretations mean that courts have failed to grasp fully the economic contribution of home labor. This is evidenced by courts' curious treatment of women who both work in the wage labor market and also do a substantial majority of the home labor, thus contributing to family wealth with wages and with home labor. This mixture of contributions, as discussed in Section III, describes most women today. But when wage-earning women try to invoke additional considerations for contribution to wealth generated by home labor, courts have responded that, despite the language of the statute, those provisions only cover the full-time homemaker. ${ }^{151}$

This judicial response indicates that courts are not recognizing the wealth created by home labor, but instead wish to show compassion for the very real financial straights in which a full-time homemaker can find herself after divorce. If judges understood home labor as creating actual material wealth, home labor would have to be counted into contribution to wealth creation in addition to the wage contribution of a wage-earning home-making spouse. Women are working longer combined hours than are men. While this does not necessarily mean that they are contributing more economic value, that conclusion is possible. ${ }^{152}$ The proposition is at least worth exploring. By refusing to credit the home labor contributions of the wage-earning home-making spouse, judges are ignoring the economic value of the home labor of the majority of women. The full-time homemaker is the exception today, not the rule, and divorce law has no provision whatsoever for capturing the economic value generated by home labor in the majority of cases. This results, at least in part, from a failure to bring a proper economic understanding of that labor into legal analysis, relying instead on an understanding of marriage roles as described by the terms "breadwinner" and "homemaker." Despite their apparent economic base, these role designations have a social significance from which economics is almost entirely removed.

It is important to remember that we might decide that the amount of contribution should not be the decisive factor in determining property allocation at the time of divorce. However, we may benefit from a clearer examination of the proper outcomes of such policy options when informed by an economic understanding. This exercise might help us clarify our goals in divorce law by presenting the possible understandings of legal obligations associated with marriage, and force us to further examine the strengths and weaknesses of marriage as the relevant institution for financially supporting the dependencies arising from childhood, illness and aging.

151. In re Marriage of Banach, 489 N.E.2d 363, 369 (III. App. Ct. 1986); In re Marriage of Stice, 779 P.2d 1020, $1027-28$ (Or. 1989); Silbaugh, supra note 2, at 62-63.

152. Here we would want to know a lot about human capital investments and how well they are being used. Also, the measurement tool chosen for valuation of home labor will be important in determining whether the typical female labor profile is contributing more value. I do not intend to make that case here. 


\section{F. Caveats on the Use of Economics}

Of course, some practical risks attend the use of economic understandings of home labor. First, there is a concrete risk that the deflated wages of the paid domestic worker will be used to estimate the value of unpaid work, as they are in the wrongful death and divorce contexts. Analysts have to be cautious in deciding which measure of the value of home labor to use. One might prefer opportunity cost as a measure, or a measure that aggregates the price of experts, such as nurses, teachers, launderers and cooks, in order to figure out the value of home labor, rather than the price of generalist housecleaners in the domestic labor market. ${ }^{153}$ More importantly, reformers should be deeply concerned about the low wages of paid domestic workers and place efforts at raising those wages at the forefront of the debate over activity within the home. Finally, the use of economic understandings may, as some fear, diminish other understandings in practice.

The answer to these concerns is to note carefully and be constantly mindful both of distortions in present valuation of home labor and in the alternative noneconomic understandings of the work. None of these reservations justify foregoing the very useful insights economics brings to the public policy questions surrounding women's home labor. We must remember the distinction between identifying questions through economic understandings and producing answers. Producing answers requires that all conceptions of an activity be considered together. It also requires an extremely detailed examination of the empirical data, with attention to the limitations of empirical knowledge that come both from data collection methodology and from the fact that facts do not explain their own causes and cannot be taken as static starting points, even when they are verifiable.

\section{CONCLUSION}

The commodification critique is often a conversation stopper. Because markets do not capture the entire experience in question, they are thought to threaten the existence of what they cannot describe. In the context of a phenomenon that is highly commodified, this argument might lead to fruitful discussions of the appropriate methods of preserving non-market understandings. In the context of phenomenon that are almost entirely non-market, however, the objection to commodification seems much weaker, because it fails to consider the potential benefits that economic understandings can bring to the social relations surrounding that non-market phenomenon. Since many of women's activities

153. See generally EUSTON QUAH, ECONOMICS AND HOME PRODUCTION: THEORY AND MEASUREMENT (1993) (exploring various studies that have measured the value of home labor and various techniques that can be used, along with strengths and weaknesses). 
have historically occurred outside of the market, a normative position against market reasoning about home activities is nearly equivalent to a normative position against market reasoning about women's activities. As long as women's economic power remains a central concern of feminist discourse, this aversion to market analysis is detrimental to feminist reform. Understanding the economic aspects of women's non-market activity is an important part of the transformative vision of a progressive feminism. Only after asking questions about the relationship between non-market reasoning and women's economic weakness can we decide what kinds of policy changes will benefit women both as a class, and as divided by differences that are relevant to economic status. By comparison, concern about a world where women's lives are stripped of all but their monetary value seems a fairly abstract one. 
